ВІСНИК

ОДЕСЬКОГО НАЦІОНАЛЬНОГО

МОРСЬКОГО УНІВЕРСИТЕТУ

№ 2 (62), 2020
HERALD

OF THE ODESSA NATIONAL

MARITIME UNIVERSITY

№ 2 (62), 2020

УДК $629.5 \mathrm{E30}$

DOI 10.47049/2226-1893-2020-2-29-44

\title{
ОБОСНОВАНИЕ ПАРАМЕТРОВ МЕЛКОСИДЯЩИХ \\ НЕФТЕНАЛИВНЫХ НЕСАМОХОДНЫХ СУДОВ ДЕДВЕЙТОМ 6000 ТОНН ДЛЯ РЕКИ БЕЛАЯ
}

\section{Г.В. Егоров}

д.т.н., профессор, генеральный директор

И.А. Ильницкий

первый зам. генерального директора, главный конструктор

\author{
А.Г. Егоров
}

к.т.н., ст. научн. сотрудник

Морское инженерное бюро, Украина, Одесса

Аннотация. Обоснован кониепт несамоходной нефтеналивной баржи типа «Белмакс» проекта ROB20. Проанализированы путевые условия реки Белая. Определены основные характеристики, разработана конструкция корпуса баржи с учетом выполнения требований МАРПОЛ. Полученьы габаритные размеры (длина х иирина х высота борта) 118 м х 22, 6 м х 3,0 м, что позволило обеспечить при озерном классе «O 2,0» при осадке 2,20 м грузоподъемность в 4575 тонн, при осадке 1,80 м - 3544 тонн, а при максимальной осадке 2,75 м - 6000 тонн. Выполнен сравнительный анализ разработанного концепта с баржами-аналогами. Старые баржи типа «Бельская» проекта P-27 с речным классом «Р» (либо неполноклассном «O 1,5») в исходном однокорпусном варианте при осадке 1,80м берут на борт 2960 тонн груза, а при максимальной осадке 2,60 м-4590 тонн.

Характеристики баржи проекта ROB20 - 6000 тонн груза (осадка 2,75 м) при массе порожнем 880 тонн вполне позволяют причислить проект кряду уникальных .

Ключевые слова: речные перевозки нефтепродуктов, несамоходное судно, проектирование, конструкция, безопасность, экологичность.

УДК $629.5 \mathrm{E30}$

DOI 10.47049/2226-1893-2020-2-29-44

ОБГРУНТУВАННЯ ПАРАМЕТРІВ НАФТОНАЛИВНИХ

НЕСАМОХІДНИХ СУДЕН 3 МАЛОЮ ОСАДКОЮ ДЕДВЕЙТОМ 6000 ТОНН ДЛЯ РІЧКИ БІЛА

Г.В. Сгоров

д.т.н., професор, генеральний директор

І.А. Ільницький

перший заст. генерального директора, головний конструктор

О.Г. Сгоров

к.т.н., ст. наук. співпрацівник

Морське інженерне бюро, Украӥна, Одеса

() Егоров Г.В., Ильницкий И.А., Егоров А.Г., 2020 
Анотація. Обтрунтовано конщепт несамохідної нафтоналивної баржі типу «Білмакс» проекту ROB20. Проаналізовано шляхові умови річки Біла. Визначено основні характеристики, розроблено конструкиію корпусу баржі з урахуванням виконання вимог МАРПОЛ. Отримано габаритні розмірення (довжина х ширина х висота борта) 118 м х 22,6 м x 3,0 м, щцо дозволило забезпечити при озерному класі «O 2,0» при осадиі 2,20 м вантажсопідйомність в 4575 тонн, при осадиі 1,80 м- 3544 тонн, а при максимальній осадиі 2,75 м - 6000 тонн. Виконано порівняльний аналіз розробленого конщепту з баржами-аналогами.

Старі баржі типу «Бельська» проекту $Р-27$ з річковим класом «P» (або неповнокласним «O 1,5») в вихідному однокорпусному варіанті при осадиі 1,80м беруть на борт 2960 тонн вантажу, а при максимальній осадиі 2,60 м-4590 тонн.

Характеристики баржі проекту ROB20 - 6000 тонн вантажу (осадка 2,75м) при масі порожньому 880 тонн иілкком дозволяють зарахувати проект до ряду унікальних.

Ключові слова: річкові перевезення нафтопродуктів, несамохідне судно, проектування, конструкція, безпека, екологічність.

UDC 629.5 E30

DOI 10.47049/2226-1893-2020-2-29-44

\title{
SUBSTANTIATION OF PARAMETERS OF 6000 DWT SHALLOW-DRAUGHT NON-SELF-PROPELLED OIL TANKERS FOR THE RIVER BELAYA
}

\author{
G. Yegorov \\ Doctor of Technical Sciences, Professor, General Director \\ I. llnytskyi \\ First Deputy General Director, Chief Designer \\ A. Egorov \\ Candidate of Technical Sciences, Senior Researcher \\ Marime Engineering Bureau, Ukraine, Odessa
}

\begin{abstract}
Concept of non-self-propelled oil barge of «Belmax» type of ROB20 project is grounded. Way conditions of the river Belaya are analyzed. Main characteristics are defined; hull's structure of barge with account of requirements of MARPOL is developed. Overall dimensions (length $x$ breadth $x$ depth) of $118 \mathrm{~m} \times 22,6 \mathrm{~m} \times 3,0 \mathrm{~m}$ were obtained, which made possible to provide 4575 tons cargo capacity with 2,20 m draught, 3544 tons with $1,80 \mathrm{~m}$ draught, and 6000 tons with maximum draught of 2,75 m. Comparative analysis of developed concept with barges-analogues is executed. Old «Belskaya» type barges of $R-27$ project with river class «R» (or not full class «O 1,5») in original single-hull version with 1,80 m draught take 2960 tons of cargo onboard and with maximum draught of 2,60 m-4590 tons.
\end{abstract}


Characteristics of ROB20 barge - 6000 tons of cargo (at 2,75 m draught) with 880 tons lightweight allow to rank the project to unique.

Keywords: river oil product transportations, non-self-propelled vessel, design, structure, safety, ecology.

Постановка проблемы. В соответствии с вновь введенным Техническим регламентом (ТР-2012) о безопасности объектов внутреннего водного транспорта все нефтеналивные суда (кроме стоечных) грузоподъемностью более 600 тонн, как новые, так и находящиеся в эксплуатации, после 31 декабря 2017 года должны были стать «двухкорпусными» - с двойными дном и бортами, простирающимися по всей длине и высоте грузовых танков.

Столь серьезный шаг для обеспечения защиты окружающей среды создал барьер для значительной части старых серий танкеров и барж, построенных ранее [1]. Помимо известных проблем в восточных бассейнах следует отметить сегмент нефтеналивных мелкосидящих барж, предназначенных для работы по реке Белая для перевозки экспортных нефтепродуктов. Это вполне «свежие» баржи с двойными бортами и одинарным утолщенным днищем проекта 82380, построенные в 20022003 годах, но не отвечающие требованиям ТР-2012, и классические однокорпусные баржи проекта Р-27 типа «Бельская», самые молодые из которых были построены в 1975 году.

Фактически это означало, что с навигации 2018 года [6] только 4 баржи проекта 82230 будут работать по реке Белой, а также баржи проекта Р-27, которые прошли существенное переоборудование путем установки второго дна, второго борта и увеличением высоты борта (таких было пять). Кроме того, там же работают две баржи проекта 81770 меньшей грузоподъемности, у которых также было установлено второе дно.

При этом в 2011 году мелкосидящие однокорпусные баржи типа «Бельская» в составе с толкачами «Урал» вывезли по реке Белая с уфимской группы нефтеперегонных заводов 880 тыс. тонн нефтепродуктов, в навигацию 2010 года - 550 тыс. тонн, в 2012 году - до 1 млн. тонн. Еще раньше перевозки мазута составляли до 150 тыс. тонн в месяц. В 2018 году объем таких перевозок после возобновления дноуглубления составил уже 1,1 млн. тонн ${ }^{1}$. При этом средние сроки навигации $-\mathrm{c}$ 25 апреля по 10 ноября, т.е. почти 7 месяцев.

Чтобы обработать этот грузопоток, необходимы были новые «двухкорпусные» нефтеналивные баржи.

\footnotetext{
${ }^{1}$ Обсуждается возобновление перевозок по реке Уфа, что может дать дополнительный объем грузов в район Уфы [7]
} 
ВІСНИК

ОДЕСЬКОГО НАЦІОНАЛЬНОГО

МОРСЬКОГО УНІВЕРСИТЕТУ

№ 2 (62), 2020
HERALD

OF THE ODESSA NATIONAL

MARITIME UNIVERSITY № 2 (62), 2020

Целью статьи является определение основных характеристик новых несамоходных речных судов «Белмакс» класса с описанием процесса проектирования и строительства.

Изложение основного материала. 19 апреля 2018 года на Окской верфи был спущен на воду головной несамоходный танкер «Белмакс 1» проекта ROB20 грузоподъемностью 6000 тонн при осадке 2,75 м, начавший серию из восьми нефтеналивных барж типа «Белмакс» речного плавания. Уже 17 мая судно было принято Заказчиком и ушло под погрузку (см. рисунок 1). Еще шесть судов были сданы в 2018 году, восьмая баржа - в 2019 году.

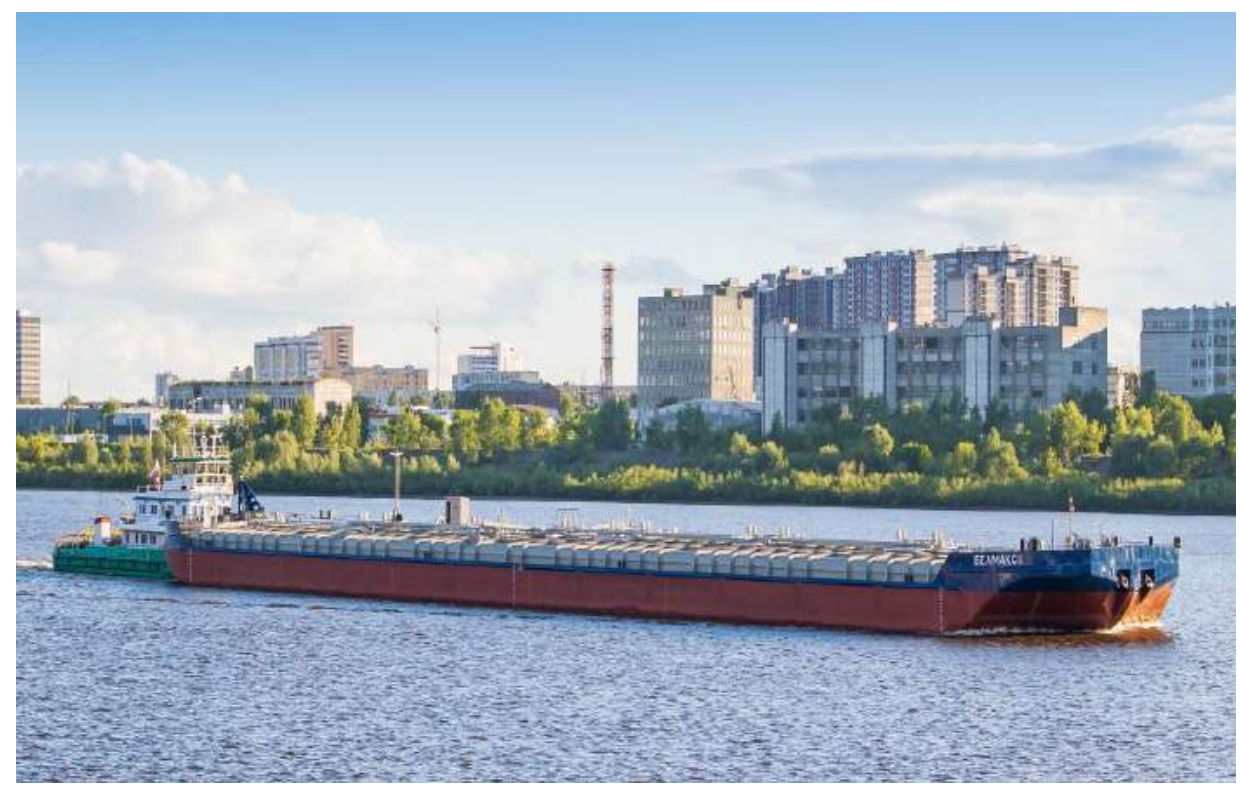

Рис. 1. «Урал 34» толкает «Белмакс 1»

Автор фотографии - Сергей Морозов

Проект ROB20 разработан Морским Инженерным Бюро.

ООО СК «Белмакс» была поставлена задача по созданию современного, экологически безопасного, отвечающего требованиям ТР-2012, несамоходного судна для выполнения главной задачи - доставки мазута с нефтеперегонных заводов Башкирии, расположенных на реке Белая, на порты Волги, вплоть до Астрахани, с возможностью эксплуатации через водохранилища разряда «О» без снижения грузоподъемности и без уменьшения допускаемой высоты волны. 
Предусматривалось использование буксиров-толкачей типа Урал/ Волгарь» мощностью 572-610 кВт длиной 32 м, дооборудованных для возможности буксировки нефтеналивных барж, перевозящих грузы с температурой вспышки выше $61^{\circ} \mathrm{C}$.

Морское Инженерное Бюро разработало концепцию судна [5], отвечающую современным требованиям экологической безопасности, с максимально возможной грузоподъемностью для актуализированных (и перспективных) путевых условий и технологичностью формы и конструкции корпуса, сокращающей время постройки судна.

Фактические параметры судового хода реки Белая на дату проектирования приведены в таблице 1 .

Таблица 1

Фактические параметры судового хода реки Белая

\begin{tabular}{|l|c|c|c|}
\hline Участок & $\begin{array}{c}\text { Гарантированная } \\
\text { глубина, м }\end{array}$ & $\begin{array}{c}\text { Минимальная } \\
\text { ширина, м }\end{array}$ & $\begin{array}{c}\text { Минимальный } \\
\text { радиус } \\
\text { закругления, м }\end{array}$ \\
\hline Устье р. Уфа - Бирск & 1,60 & 50 & 300 \\
\hline Бирск - Груздевка & 1,75 & 60 & 500 \\
\hline Груздевка - Азякуль & 2,85 & 90 & 500 \\
\hline Азякуль - устье реки Белая & 4,00 & 100 & 600 \\
\hline
\end{tabular}

Выбор главных размерений был выполнен старшим научным сотрудником, к.т.н. А.Г. Егоровым на основе математического моделирования управляемости и ходкости состава $[2 ; 3]$, исходя из данных таблицы 1 при расчетной скорости течения 2,7 км/ч $(0,75 \mathrm{~m} / \mathrm{c}$, фактически летом в среднем 0,6-0,8 м/с) и скорости движения состава 10 км/ч.

Предполагается, что в результате начатого Росморречфлотом дноуглубления на участке Уфа - Груздевка гарантированная глубина в межень будет доведена до 2,25 м, ширина судового пути до 60 м, а радиус до 600 м.

В итоге, были получены габаритные размеры (длина $\mathrm{x}$ ширина $\mathrm{x}$ высота борта) 118 м х 22,6 м х 3,0 м (см. рисунок 2), что позволило обеспечить при озерном классе «О 2,0» при осадке 2,20 м грузоподъемность в 4575 тонн, при осадке 1,80 м - 3544 тонн, а при максимальной осадке 2,75 м - 6000 тонн. Старые баржи типа «Бельская» проекта Р-27 с речным классом «Р» (либо неполноклассным «О 1,5») в исходном однокорпусном варианте при осадке 1,80 м берут на борт 2960 тонн груза, а при максимальной осадке 2,60 м - 4590 тонн (см. таблицу 2). 
ВІСНИК

ОДЕСЬКОГО НАЦІОНАЛЬНОГО

МОРСЬКОГО УНІВЕРСИТЕТУ

№ 2 (62), 2020
HERALD

OF THE ODESSA NATIONAL

MARITIME UNIVERSITY № 2 (62), 2020

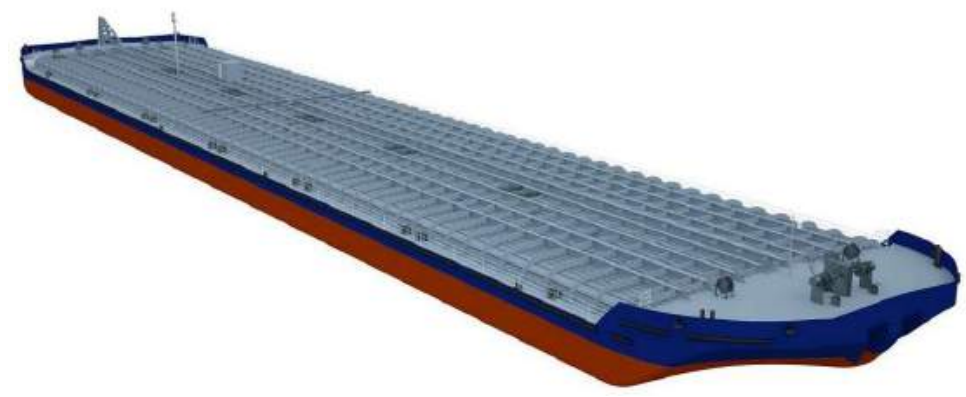

Рuс. 2. Трехмерная модель баржи проекта ROB20

Таблица 2

Сравнение характеристик нефтеналивной баржи типа «Белиакс» и наиболее близких существуюших нефтеналивных барж

\begin{tabular}{|c|c|c|c|}
\hline Характеристика & $\begin{array}{l}\text { «Белмакс } 1 » \\
\text { Пр. ROB20 }\end{array}$ & Пр. 82380 & Пр. Р27 \\
\hline Класс судна & MO2,0 & $1 \times 1,2$ & 1 1,2 \\
\hline Длина наибольшая, м & 118,79 & 107,03 & 111,2 \\
\hline Длина по КВЛ, м & 117,775 & 106,1 & 110,0 \\
\hline Ширина габаритная, м & 22,80 & 21,07 & 20,4 \\
\hline Ширина, м & 22,60 & 21,0 & 20,0 \\
\hline Высота борта до главной палубы, м & 3,00 & 3,00 & 2,85 \\
\hline Высота тронка, м & 1,00 & Нет & Нет \\
\hline Высота расчетная, м & 4,00 & 3,0 & 2,85 \\
\hline Осадка по ЛГВЛ, м & 2,75 & 2,75 & 2,60 \\
\hline $\begin{array}{l}\text { Высота габаритная } \\
\text { от ОП до верха несъемных частей, м }\end{array}$ & 8,20 & 8,20 & 6,20 \\
\hline Количество грузовых танков & 12 & 10 & 15 \\
\hline Количество отстойных танков & 2 & 1 & Нет \\
\hline Наличие двойного дна & Да & Нет & Нет \\
\hline Наличие двойных бортов & Да & Да & Нет \\
\hline $\begin{array}{l}\text { Вместимость грузовых танков } \\
\text { (максимальная, включая } 1 \text { отстойный } \\
\text { и шахту выгрузки), м }\end{array}$ & $\begin{array}{c}6530 \\
(6860)\end{array}$ & 5379 & 5785 \\
\hline Вместимость отстойных танков, м $^{3}$ & 340 & 153,3 & - \\
\hline Наличие подогрева груза & Да & Да & Да \\
\hline $\begin{array}{l}\text { Грузоподъемность } \\
\text { при осадке по ЛГВЛ, т }\end{array}$ & $\begin{array}{c}6000 \\
(2,75 \mathrm{M})\end{array}$ & $\begin{array}{c}4710 \\
(2,75 \mathrm{M})\end{array}$ & $\begin{array}{c}4587 \\
(2,60 \mathrm{M}) \\
\end{array}$ \\
\hline Спецификационная плотность груза, т/м³ & 0,875 & 0,876 & 0,793 \\
\hline $\begin{array}{l}\text { Коэффициент использования } \\
\text { водоизмещения по грузоподъемности }\end{array}$ & 0,870 & 0,870 & 0,903 \\
\hline Грузоподъемность (при осадке 2,20 м), т & 4575 & 3632 & 3774 \\
\hline Грузоподъемность (при осадке 1,80 м), т & 3544 & 2817 & 2960 \\
\hline
\end{tabular}


ВІСНИК

ОДЕСЬКОГО НАЦІОНАЛЬНОГО

МОРСЬКОГО УНІВЕРСИТЕТУ № 2 (62), 2020
HERALD

OF THE ODESSA NATIONAL

MARITIME UNIVERSITY № 2 (62), 2020

При проектировании корпуса проекта ROB20 широко применялись расчетные методы, что позволило «скомпенсировать» появление дополнительных второго дна и второго борта, поэтому обеспечена грузоподъёмность до 6000 тонн при осадке 2,75 м. Это безусловно рекорд для судов внутреннего плавания.

Когда-то такие же рекорды ставили первые в мире нефтеналивные баржи, которые имели также очень длинную и плоскую конструкцию корпуса при минимальной массе корпуса. В 1884 году их спроектировал выдающийся инженер Владимир Григорьевич Шухов [8]. В Царицыне и Саратове потом построили 65 таких барж, элементы корпуса которых были получены не набором по правилам, а на основе прямых расчетов прочности, причем с учетом уменьшения изгибающего момента, действующего на корпус при общем изгибе, за счет гибкости самого корпуса.

Назначение судна проекта ROB20 - перевозка нефтеналивных грузов с температурой вспышки $60{ }^{\circ} \mathrm{C}$ и выше, основной груз - мазут. Расчетный диапазон плотностей груза - 0,92-1,015 т/м³.

Архитектурно-конструктивный тип: несамоходная, наливная баржа с 12 грузовыми танками, с двойным дном и двойными бортами, с избыточным надводным бортом (см. рисунок 3). Высота борта баржи определена из условия получения полного использования вместимости (заполнение 98 \%) при полном использовании грузоподъемности при перевозке мазута плотностью 0,92 т/ $\mathrm{m}^{3}$.

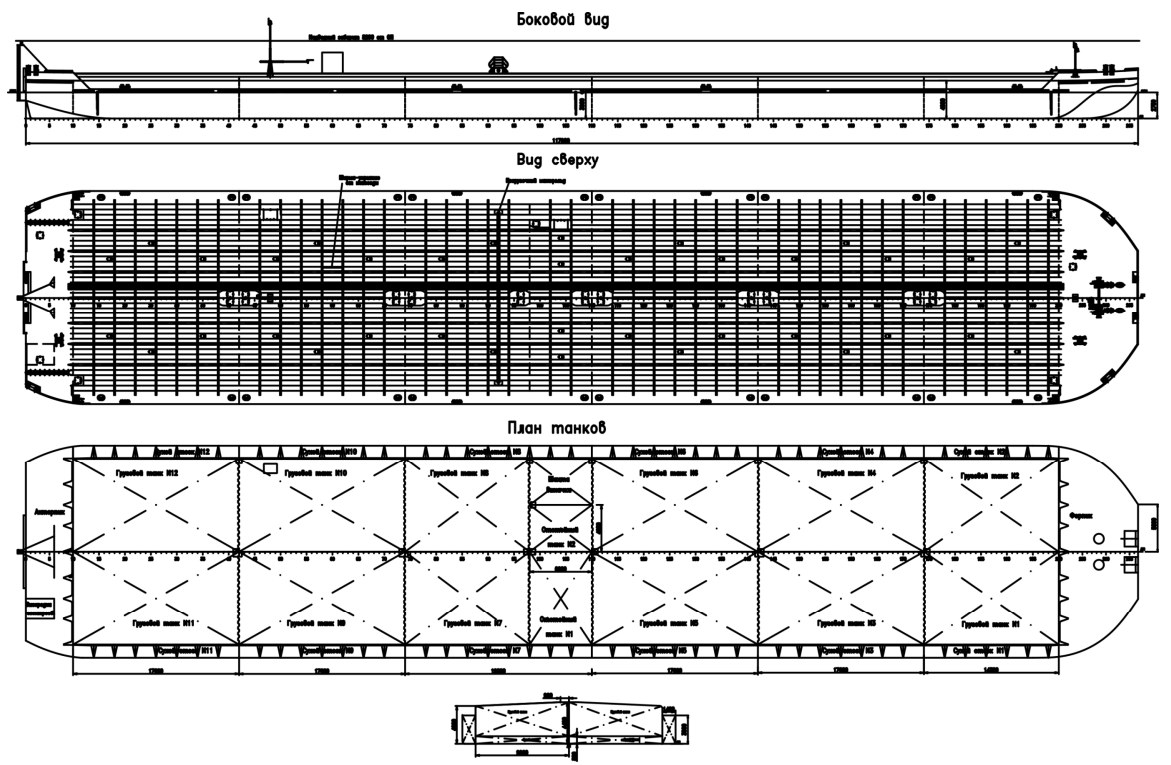

Puс. 3. Общее расположение барж проекта ROB20 типа «Белмакс» 
ВІСНИК

ОДЕСЬКОГО НАЦІОНАЛЬНОГО

МОРСЬКОГО УНІВЕРСИТЕТУ

№ 2 (62), 2020
HERALD

OF THE ODESSA NATIONAL

MARITIME UNIVERSITY № 2 (62), 2020

Назначение судна проекта ROB20 - перевозка нефтеналивных грузов с температурой вспышки $60{ }^{\circ} \mathrm{C}$ и выше, основной груз - мазут. Расчетный диапазон плотностей груза $-0,92-1,015$ т/ $\mathrm{m}^{3}$.

Эксплуатация судна осуществляется без экипажа на борту.

Для удовлетворения требований экологической безопасности (ограничение длины грузовых танков) грузовое пространство разделено на 12 грузовых танков и 2 отстойных танка продольной переборкой в ДП и 8 поперечными водонепроницаемыми переборками.

С целью улучшения мореходных качеств баржи носовая оконечность выполнена в виде килеватых саней (см. рисунок 4).

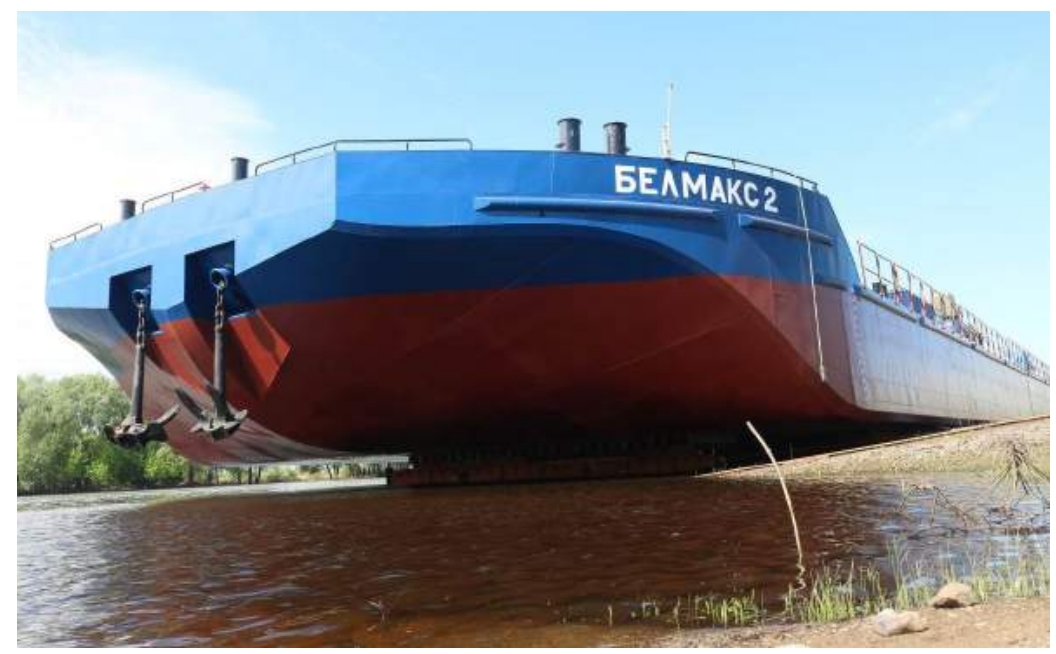

Рис. 4. Танкер «Белмакс 2»-носовые обводы

Для наилучшего использования габаритной длины баржи применен носовой транец. В остальном обводы баржи упрощены. Для устойчивости на курсе при буксировке в кормовом подзоре установлены 2 скега.

Грузовые и отстойные танки гладкостенные без набора. Набор главной палубы установлен снаружи, внутренних бортов - внутри двойных бортов. Схема мидель-шпангоута приведена на рисунке 5, вид на поперечное сечение корпуса в постройке на рисунке 6 .

В качестве основного материала корпуса применена сталь категорий $\mathrm{A}, \mathrm{D} 32$ и А36, в районе упоров буксира-толкача и сцепной балки сталь категории В.

Корпус выполнен по смешанной системе набора:

- двойное дно, внутренние борта и палубы по продольной системе;

- наружный борт и оконечности (форпик и ахтерпик) по поперечной. 
ВІСНИК

ОДЕСЬКОГО НАЦІОНАЛЬНОГО

МОРСЬКОГО УНІВЕРСИТЕТУ

№ 2 (62), 2020
HERALD

OF THE ODESSA NATIONAL

MARITIME UNIVERSITY № 2 (62), 2020

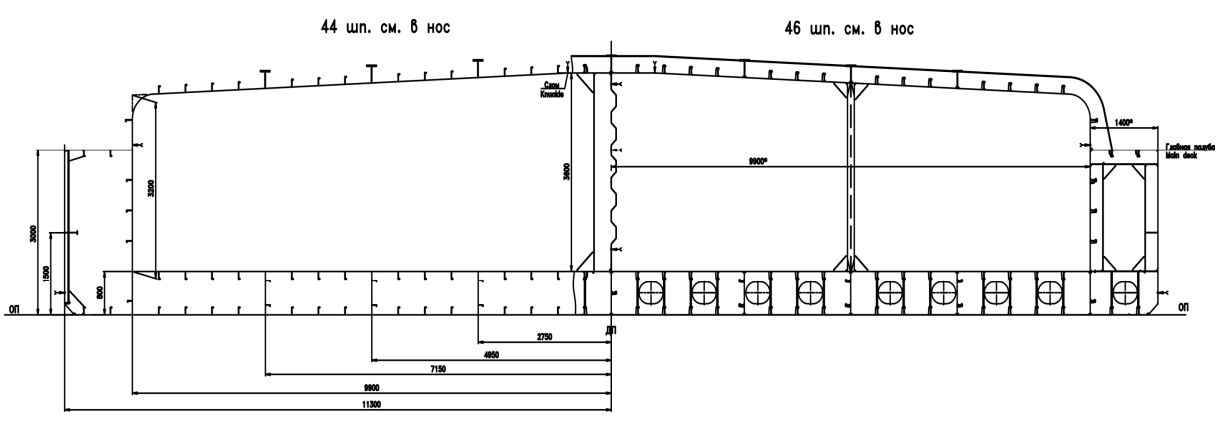

Рuc. 5. Конструктивный мидель-шпангоут барж проекта ROB20

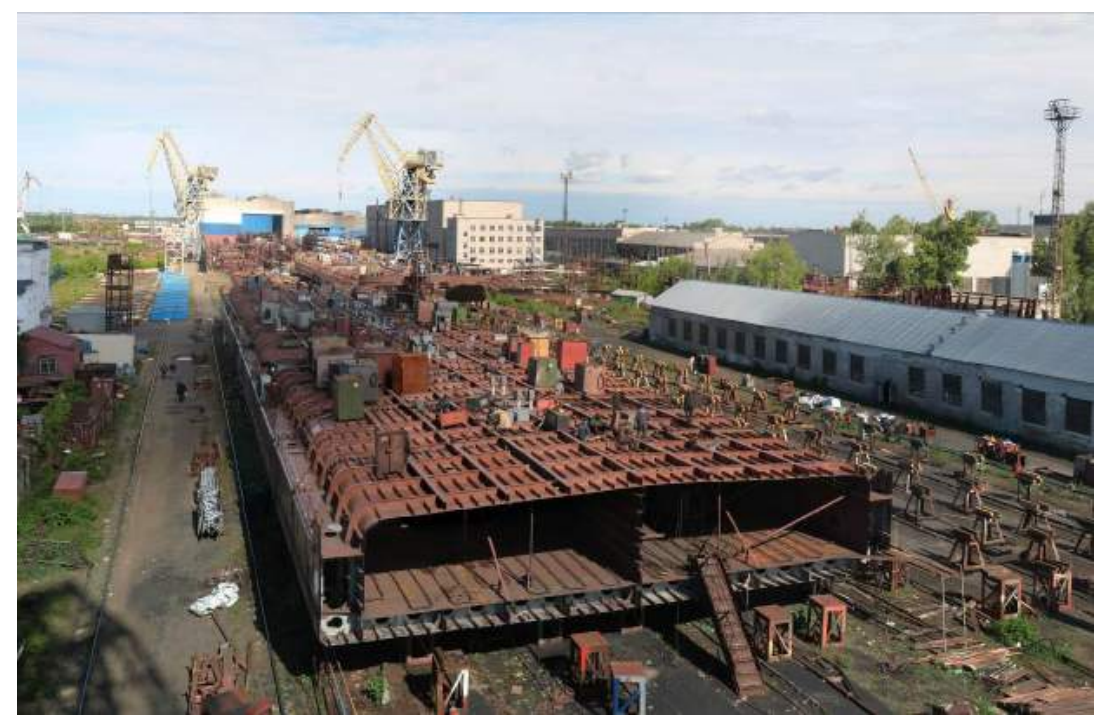

Рис. 6. Танкер «Белмакс 3»-поперечный разрез

Поперечная шпация:

- форпик и ахтерпик 500 мм;

- грузовая зона шп. 10-200 - 550 мм. 1000 мм)

Шпация поперечного рамного набора - 2200 мм (в пиках

Продольная шпация - 550 мм.

При проектировании корпусных конструкций и корпуса в целом широчайшим образом применялись прямые расчеты прочности с использованием программ конечно-элементного анализа, которые выполнила группа прочностного анализа Бюро. 
Например, на рисунке 7 приведена схема деформированного состояния конструкции расчетной объемной модели корпуса в районе шп. 110-142. Она включала в себя 107838 оболочечных и стержневых элементов и имеет 446630 степеней свободы. Модель имеет длину 17,6 м; ширину $-22,6$ м; высота- 4,40 м.

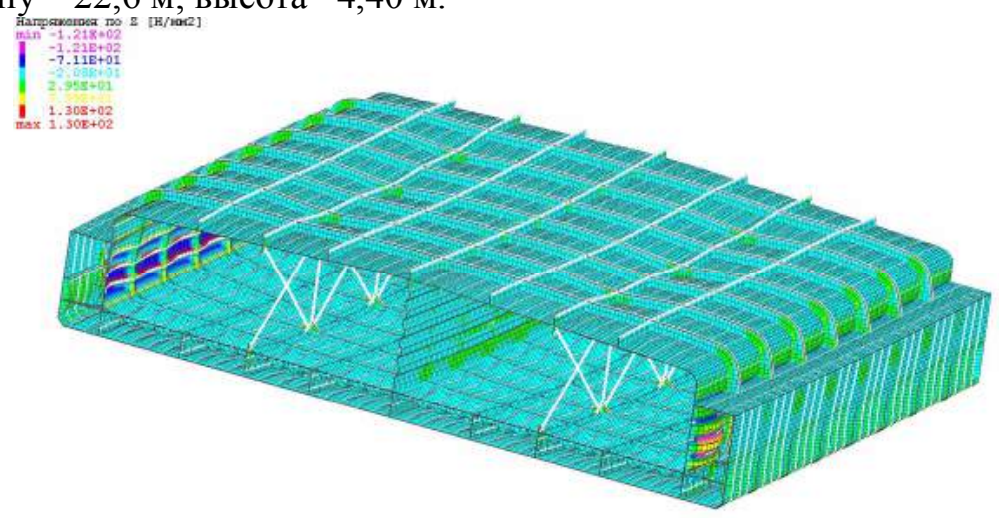

Рис. 7. Деформированное состояние конструкиии корпуса в районе ши. 110-142

Плоские конструкции, стенки моделировались прямоугольными конечными оболочечными элементами с шестью степенями свободы в узле, использовались также четырехугольные и треугольные элементы произвольной формы. Пояски и ребра жесткости моделировались стержневыми элементами.

Расчет выполнялся для состояния «судно на подошве волны». Внешняя нагрузка на днищевое перекрытие составляла с учетом полувысоты волны $(2,75-1,00)^{*} 9,81 * 1,0=17,2$ кПа. Расчетная местная нагрузка на настил 2-го дна - 39 кПа.

Было показано, что наиболее нагруженным конструкциями являются флоры (см. рисунок 8) и карлингсы палубы тронка.

Максимальные нормальные напряжения во флорах возникли в пролетах в районе вырезов и составили 166 МПа или 74,4 \% от допускаемых. Максимальные касательные напряжения во флорах составили 80,7 МПа или 75,3 \% от допускаемых. Максимальные нормальные напряжения в карлингсах возникли в опорном сечении и с учетом напряжений от общего изгиба корпуса составили 160,4 МПа или 71,8 \% от допускаемых. В остальных рамных связях и продольных ребрах жесткости напряжения были существенно меньше.

Общая прочность корпуса судна пр. ROB20 по предельному моменту в условиях класса «О 2,0» выполнялась с $64 \%$ запасом, что принципиально важно для фактических условий работы этих барж, так как их предшественники - баржи проекта Р-27, построенные на класс «Р 1,2» неоднократно получали переломы корпусов [4]. 
ВІСНИК

ОДЕСЬКОГО НАЦІОНАЛЬНОГО

МОРСЬКОГО УНІВЕРСИТЕТУ

№ 2 (62), 2020
HERALD

OF THE ODESSA NATIONAL

MARITIME UNIVERSITY № 2 (62), 2020

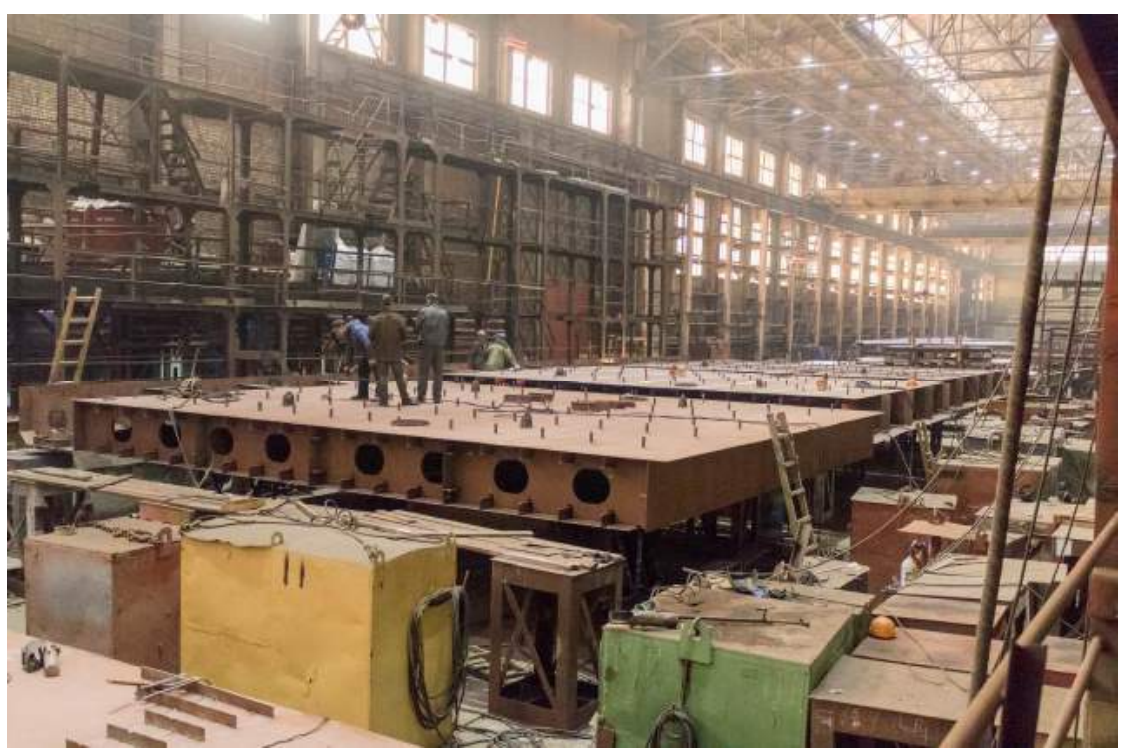

Рис. 8. Двойное дно баржи проекта ROB20

Источником электроэнергии барже-буксирного состава в ходовом режиме является электростанция буксира-толкача с напряжением $230 \mathrm{~B}$. Потребители электроэнергии баржи получают питание через щиты питания, оборудованные силовыми штепсельными разъёмами, расположенные на палубе в кормовой части.

На судне устанавливаются группа аккумуляторных батарей. Батареи размещаются в аккумуляторном ящике водозащищенного исполнения и установлены в выгородке для электрооборудования в корме.

Вид на палубу баржи представлен на рисунке 9. Судно снабжено двумя носовыми якорями типа Холла массой по 1500 кг каждый. Якоря убираются в клюзы. Якорные цепи сварные с распорками, калибром 34 мм, 2 категории прочности, длиной 150 м каждая хранятся в цепных ящиках, обеспечивающих самоукладку цепей.

Крепление становых якорей по-походному осуществляется роликовыми стопорами. Предусмотрена дистанционная отдача правого якоря.

Для подъема и отдачи становых якорей на палубе бака установлена электрическая якорно-швартовная лебедка с двумя якорными звездочками и двумя швартовными турачками. Электропитание лебедки от буксира-толкача.

Управление якорно-швартовной лебедкой осуществляется с местного поста управления устанавливаемого рядом с лебедкой.

В цепных ящиках имеются устройства для крепления и экстренной отдачи якорных цепей, приводы которых выведены на открытую палубу в районе якорно-швартовной лебедки. 


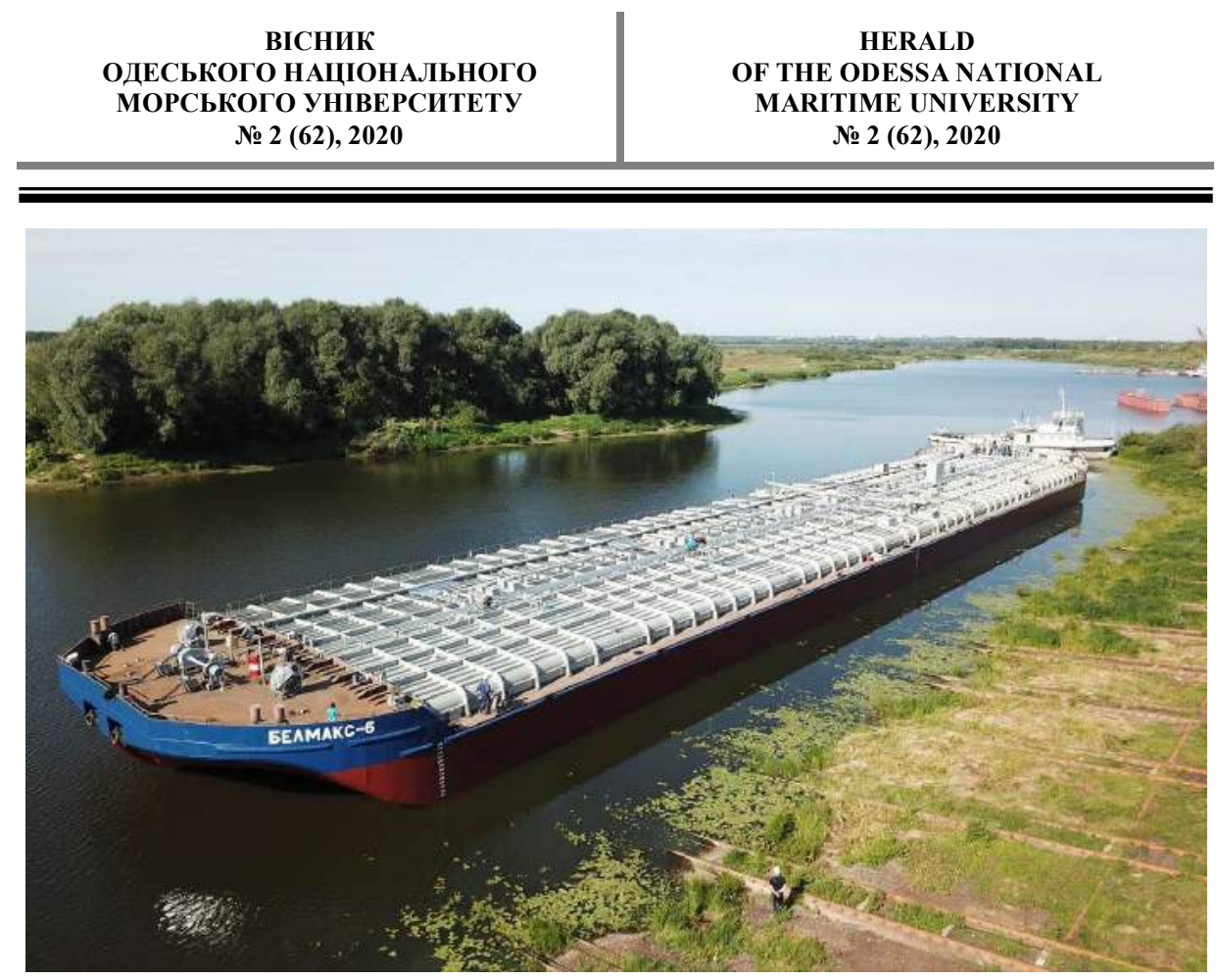

Рис. 9. Вид на палубу баржи «Белмакс 6»

Предусмотрена дистанционная отдача правого якоря с рулевой рубки судна-толкача.

В кормовой оконечности установлена вертикальная сцепная балка для автоматического сцепного замка типа О-200. Для счала буксиратолкача проекта Р45Б с наливной баржей проекта ROB20 в толкаемый состав с помощью вожжевых тросов предусмотрены в кормовой оконечности баржи на палубе юта натяжные устройства УНО-40.

Для буксировки предусматриваются парные буксирные кнехты, установленные в носовой и кормовой оконечностях. Для наводки толкача при сцепных операциях в корме на транце установлены два сварных кнехта типа 1Б-219.

В носу в качестве направляющих буксирного троса установлены два парных кнехта. Буксировка обеспечивается на полубрагах.

Грузовая система обеспечивает закрытый прием груза несудовыми средствами с обоих бортов с производительностью до $1000 \mathrm{~m}^{3} /$ ч через манифольд DN250, расположенный в средней части судна.

Каждый грузовой танк оборудован наливной трубой с затвором DN150. Максимальная интенсивность погрузки грузового танка составляет $500 \mathrm{~m}^{3} /$ ч (отстойного - $350 \mathrm{~m}^{3} /$ ч). Заполнение шахты выкачки производится из смежных грузовых танков (№ 6 или № 8) через перепускные переборочные задвижки. 
Для обеспечения скорости потока на выходе приемного трубопровода в танке не более $1 \mathrm{~m} / \mathrm{c}$ в начальной стадии погрузки интенсивность погрузки грузового танка не должна превышать $60 \mathrm{~m} 3 / 4$ (отстойного $\left.40 \mathrm{~m}^{3} / \mathrm{ч}\right)$.

На открытую палубу выведены обобщенные световой и звуковой сигналы о достижении предельных и аварийных уровней жидкости в танках и о срабатывании АПС по температурам в танках.

Выгрузка производится закрытым способом средствами нефтеперекачивающей станции (НПС) с производительностью до 800 м $3 / 4$, груз удаляется насосами НПС через манифольд, расположенный в грузовом танке № 10, куда груз перетекает через перепускные задвижки, установленные на всех смежных переборках грузовых танков.

Для обеспечения полного слива груза перепускные задвижки устанавливаются в выгороженные во втором дне колодцы. Управление запорной арматурой, расположенной в танках, ручное дистанционное, с помощью валиковых приводов, выведенных на палубу тронка.

Вентилирование грузовых и отстойных танков, а также пространств двойного корпуса производится переносным вентилятором.

Продувка порожних грузовых и отстойных танков производится для удаления из них воспламеняющихся паров и токсичных газов. Переносной вентилятор устанавливается на моечные горловины. Отвод воздуха из грузовых и отстойных танков осуществляется через люки или газоотводные трубы.

Мойка танков обеспечивается береговыми средствами (зачистных станций), с использованием переносных моечных машинок, устанавливаемых в танках через моечные горловины, имеющиеся на каждом танке. Выкачка промывочной воды осуществляется из шахты выкачки с помощью переносных средств зачистных станций, а также береговыми грузовыми насосами.

Все грузовые и отстойные танки, а также шахта выкачки оборудуются змеевиками подогрева, выполненными из стали. Система подогрева обеспечивает поддержание температуры перевозимого груза около $60{ }^{\circ} \mathrm{C}$.

Регулирование температуры груза в танках осуществляется с помощью ручных клапанов, установленных перед входом змеевика в танк. Предусмотрена индикация температуры груза и АПС по низкой и высокой температуре в каждом танке.

Снабжение системы паром производится от котлоагрегата буксира-толкача (4,8 т/ч пара с давлением 0,69 Мпа). Конденсат из змеевиков отводится через конденсатоотводчики от каждой секции самостоятельно в общую магистраль конденсата и далее поступает в систему буксиратолкача. Подача пара на баржу и возврат конденсата на буксир производится через кормовые манифольды. Манифольды пара и конденсата, 
установленные в средней части судна, предназначены для приема пара с берега и возврата конденсата на берег.

Противопожарная защита судна осуществляется средствами буксира-толкача. Для этого буксир-толкач оборудован системой водотушения и системой пенотушения.

Осушение пиков, сухих отсеков, цепных ящиков и выгородки электрооборудования производится водоструйными переносными эжекторами с подачей до $20 \mathrm{~m}^{3} /$ ч каждый через трубы с приемными сетками в нижней части и измерительными втулками на палубе, к которым подключается всасывающий рукав переносного эжектора.

Заключение. Характеристики баржи проекта ROB20 - 6000 тонн груза (осадка 2,75 м) при массе порожнем 880 тонн вполне позволяют причислить проект к ряду уникальных.

При проектировании корпуса проекта ROB20 габаритными размерами (длина х ширина х высота борта) 118 м х 22,6 м х 3,0 м широко применялись расчетные методы, что позволило «скомпенсировать» появление дополнительных второго дна и второго борта, поэтому обеспечена грузоподъёмность до 6000 тонн при осадке 2,75 м. При осадке 2,20 м 4575 тонн, 1,80 м - 3544 тонн.

Новые баржи могут перевозить нефтеналивные грузы с температурой вспышки $60{ }^{\circ} \mathrm{C}$ и выше, основной груз мазут, по реке Белой реке Волга, включая водохранилища. Поэтому класс Российского Речного Регистра «озерный»-О 2,0.

Для сведений, старые баржи типа «Бельская» проекта Р-27 с речным классом «Р», в исходном однокорпусном варианте при осадке 1,80 м берут на борт 2960 тонн груза, а при максимальной осадке 2,60 м 4590 тонн.

Так что налицо увеличение возможностей новых барж проекта ROB20, как по массе перевозимого груза, так и по классу судна, плюс «двухкорпусность» - как базовый критерий.

\section{СПИСОК ЛІТЕРАТУРИ}

1. Егоров Г.В. Танкерный флот вне закона? Новый техрегламент запретит эксплуатациию больиинства танкеров речного и смешанного плавания // Морские вести России. 2014. № 18. C. 10-11.

2. Егоров А.Г. Математическая модель определения главных характеристик составных судов // Морской Вестник. 2015. № 2 (54). C. 85-89. 
ВІСНИК

ОДЕСЬКОГО НАЦІОНАЛЬНОГО

МОРСЬКОГО УНІВЕРСИТЕТУ

№ 2 (62), 2020
HERALD

OF THE ODESSA NATIONAL

MARITIME UNIVERSITY

3. Егоров А.Г. Оиенка массы корпуса грузовых судов внутреннего и смешанного плавания на стадии эскизного проектирования // Труды Крыловского государственного научного иентра. 2015. № 89.2 (373.2). C. 175-190.

4. Егоров А.Г. Анализ аварийности барже-буксирных составов внутреннего и смешанного река-море плавания // Морской Вестник. 2016. № 2 (58). С. 103-109.

5. Егоров Г.В., Ильницкий И.А., Егоров А.Г. Особенности проектирования несамоходных нефтеналивных судов проекта ROB20 // Материалы Хмеждун. научно-техн. конф. «Инноваиии в судостроении и океанотехнике». Николаев: НУК, 2019. C. 117-119.

6. Комиссаров А.В. Суда типа «Бельская»: прошлое, настоящеe, будущее / https://www.korabel.ru/news/comments/ suda_ tipa_belskaya_proshloe_nastoyaschee_buduschee.html.

7. Сергеев С.Н. Об эффективности организации перевозок по реке Уфа. Речной транспорт (ХХІ век). 2019. № 4 (92). C. 15-19.

8. Шухов: Покоритель пространства / Александр Васьков. М.: Молодая гвардия, 2018. 415 c.

\section{REFERENCE}

1. Egorov, G.V. (2014). Tankernyy flot vne zakona? Novyy tekhreglament zapretit ekspluatatsiyu bol'shinstva tankerov rechnogo i smeshannogo plavaniya [Is tanker fleet illegal? New technical regulation will prohibit operation of most river and river-sea tankers]. Morskie vesti Rossii (Russian Sea News), 18, 10-11 [in Russian].

2. Egorov, A.G. (2015). Matematicheskaya model' opredeleniya glavnykh kharakteristik sostavnykh sudov [Mathematical model for determination of main characteristics of integrated vessels]. Morskoy Vestnik (Maritime Reporter), 2 (54), 85-89 [in Russian].

3. Egorov, A.G. (2015). Otsenka massy korpusa gruzovykh sudov vnutrennego $i$ smeshannogo plavaniya na stadii eskiznogo proyektirovaniya [Evaluation of lightweight of river and river-sea cargo vessels on the stage of preliminary design]. Trudy Krylovskogo gosudarstvennogo nauchnogo tsentra (Proceedings of Krylov state research center), 89.2 (373.2), 175-190 [in Russian]. 
4. Egorov, A.G. (2016). Analiz avariynosti barzhe-buksirnykh sostavov vnutrennego i smeshannogo reka-more plavaniya [Analysis of accident rate of river and river-sea tug-barge combinations]. Morskoy Vestnik (Maritime Reporter), 2 (58), 103-109 [in Russian].

5. Egorov, G.V., Ilnytskiy I.A., Egorov A.G. (2019). Osobennosti proyektirovaniya nesamokhodnykh neftenalivnykh sudov proyekta ROB20 [Design features of non-self-propelled oil barges of ROB20 project]. Materialy X mezhdun. nauchno-tekhn. konf. "Innovatsii $v$ sudostroenii $i$ okeanotekhnike» (Proceedings of $X$ international Sc-Tech. conference "Innovations in shipbuilding and ocean technique»). Nikolayev, 117-119 [in Russian].

6. Komissarov, A.V. (2018). Suda tipa «Bel'skaya»: proshloye, nastoyashcheye, budushcheye [Belskaya type vessels: past, present, future]. Korabel.ru website. Retrieved from: https:// www. korabel.ru/news/comments/suda_tipa_belskaya_proshloe_nastoyaschee_buduschee.html (access date 15.01.2020) [in Russian].

7. Sergeev, S.N. (2019). Ob effektivnosti organizatsii perevozok po reke Ufa [On the effectiveness of organization of transportation on the Ufa River]. Rechnoy transport XXI vek (River transport XXI century), 4 (92), 15-19 [in Russian].

8. Vaskov, A. (2018). Shukhov: Pokoritel' prostranstva [Shukhov: The Conqueror of Space]. Molodaya Gvardiya (Young Guards), 415 p. [in Russian].

Стаття надійшла до редакиії 22.04.2020

Посилання на статтю: Егоров Г.В., Ильницкий И.А., Егоров А.Г. Обоснование параметров мелкосидящих нефтеналивных несамоходных судов дедвейтом 6000 тонн для реки Белая // Вісник Одеського національного морського університету: Зб. наук. праць, 2020. № 2(62). C. 29-44. DOI 10.47049/ 2226-1893-2020-2-29-44.

Article received 22.04.2020

Reference a JournalArtic: Yegorov, G., Ilnitskyi, I., Yegorov, A. Substantiation of parameters of $6000 \mathrm{dwt}$ shallow-draught non-self-propelled oil tankers for the river Belaya // Herald of the Odessa national maritime university. 2020. 2(62), 29-44. DOI 10.47049/2226-1893-2020-2-29-44. 